\title{
Members' Satisfaction on Service Provided by Selected Cooperative Business Enterprises (CBEs) in Bedeno Woreda, East Hararghe Zone, Oromia Region
}

\author{
Ahmed Aliyi Mohammed \\ College of Business and Economics, Dire Dawa University, Ethiopia
}

\begin{abstract}
This study was conducted in Bedeno Woreda on five purposively selected primary cooperatives. Based on PPS technique 344 members were selected as sample size. The required data was collected from both secondary and primary sources. Primary data was collected from 334 selected members using semi-structured interview. The collected data was analyzed by using descriptive analytical tools like frequency analysis, percentage and crosstab analysis. The result of descriptive statistics showed that majority of member respondents were not satisfied on services provided by CBEs. It is recommended that the cooperatives have to offer quality service at low cost and provide high price for member'output by searching new market like foreign market. Cooperatives have to fairly distribute service and should be based on customer/member oriented principle. Cooperatives have to focus on extending the existing service and offering other required services.
\end{abstract}

Keywords: Primary Agricultural Cooperatives, Member'Satisfaction, Cooperative Services

DOI: $10.7176 / \mathrm{JMCR} / 63-03$

Publication date: December $31^{\text {st }} 2019$

\section{INTRODUCTION}

\subsection{Background}

Cooperative is an enterprise in which individuals voluntarily organize to provide themselves and others with goods and services via democratic control and for mutually shared benefit. Moreover, cooperatives often provide education and training to their members. It is both an association and an enterprise. The enterprise aspect gives primacy to the economic and business functions of cooperative. A cooperative enterprise comes into being when the participating members decide to establish a joint enterprise or undertaking, which is collectively operated (Burt, 1997).

The survival of any cooperatives depends on their capability of satisfying their members. Members are those who organize cooperative to solve their problem collectively by organizing their knowledge, efforts and capital together. Members are the user, the owner, controller as well as the customers of the cooperatives. Their satisfaction is the major objective of their cooperative. Cooperatives exist to address members' needs by providing services such as helping members market their products and buy farm supplies, financial services and retailed goods, etc. They are also used as tools in addressing a broad range of socio-economic pressures such as unemployment, youth employment, value-added industries in rural communities and access to health care (Henry A Dakurah et al, 2005).

The efficiency of a cooperative enterprise is measured primarily, not in terms of return on investment, but in terms of quality, adequacy, and cost of service rendered to member users (Knapp, 2000).

\subsection{Statement of the problem}

'When individuals find it difficult to provide themselves with the basic socio - economic services they need on regular basis cooperation becomes the best option (Aref, 2011). Cooperative societies assume a major role in the supply of some essential services in the rural sector such as supply of credit and inputs, marketing and processing facilities. Barton (1989) agrees that agricultural cooperatives provide significant economic incentives which include achieving more favorable prices, patronage refunds, providing services which would not be available otherwise, or to secure sources of inputs and access to certain markets. By providing this service, cooperatives contribute to the development of the economy of the country. According to Anderson and Vince (2000) customer expectation about types and quality services that should be offered and their criteria for performance of these services have a major impact on level of satisfaction or dissatisfaction felt with total services. Member'satisfaction does have a positive effect on an organization's sustainability. Satisfied members form the foundation of any successful business as members' satisfaction leads to high member'participation, loyalty, and develop positive image of cooperative. From time to time it is important to check whether cooperatives are satisfying their members or not. In general, available literatures show that there are a few studies which have been conducted on member'satisfaction on services of cooperatives which is yet done in Bedeno. This study is an attempt to address the research gap on member'satisfaction on service of CBEs in the study area. 
So, in this study the attempt was made to find answers for the following key questions;

1) What are the services provided by CBEs in Bedeno woreda?

2) Are the members satisfied on each services provided by CBEs?

3) What is the satisfaction level of members on the services provided by CBEs?

\subsection{Objectives of the study}

The overall objective of this research is to analyze member's satisfaction on service provided by CBEs. To achieve this grand objective, the following specific objectives were addressed;

1. To describe the services provided by CBEs to members

2. To assess members' satisfaction level on services provided by CBEs

\section{REVIEW OF RELATED LITERATURE}

\subsection{Concepts of Cooperatives}

A cooperative is an autonomous association of persons united voluntarily to meet their common economic, social and cultural needs and aspirations through a jointly owned and democratically controlled enterprise (ICA, 1995). This definition of cooperative society is usually supplemented with the distinguishing features of cooperatives encapsulated in the seven cooperative principles of (1) voluntary and open membership, (2) democratic member control, (3) member economic participation, (4) autonomy and independence, (5) education, training and information, (6) cooperation among cooperatives and (7) concern for community. Cooperative societies function on the basis of the values of self-help, self-responsibility, democracy, equality, equity and solidarity. In the tradition of the founders of the cooperative movement, cooperative members believe in the ethical values of honesty, openness, social responsibility and caring for others (ICA, 1995).

Cooperative activities usually target the poor and the under-served segments of the society (DFID, 2010). When individuals find it difficult to provide themselves with the basic socio - economic services they need on regular basis cooperation becomes the best option (Aref, 2011). Cooperative services span through all the gamut of human needs including housing, health services, education, farming, finance, marketing and power supply (ICA, 1995).

According to the National Cooperative Business Association (NCBA, 2007), cooperatives can supply services to their members which other suppliers are unwilling to do. They can increase the bargaining power of individuals enabling them to obtain services and products at more favorable prices. Hence, cooperatives exist to serve the interests of their member.

\subsection{Member'Satisfaction}

Many authors defined satisfaction by different terms. Kotler (2000) defined satisfaction as: “a person's feelings of pleasure or disappointment resulting from comparing a product perceived performance (or outcome) in relation to his or her expectations". According to Hansemark and Albinson (2004) as cited by Ankit Shah (2012) "satisfaction is an overall customers' attitude towards a service provider, or an emotional reaction to the difference between what they anticipate and what they receive, regarding the fulfillment of some needs, goals or desire". Member'satisfaction is the primary objective of cooperatives. Members are the owners, the users (customers) and controller of their cooperatives. As customers of cooperative members need must be achieved by their cooperatives. The overall member'satisfaction on service of their cooperative leads to members to continue their membership, to actively participate in activities of the cooperative and also to develop positive image of the cooperative which attracts non-members toward membership of the cooperative.

According to Oliver (1997), as cited by Ankit Shah (2012) customer satisfaction is an evaluation by the customer, after buying goods and services. The most time-honored view of customer satisfaction in the academic world is that customer satisfaction is the judgment assumed out of the comparison of pre-purchase expectations with post-purchase evaluation of the product or service. Accordingly, member'satisfaction is an evaluation by members after they receive the services to judge whether their cooperative are working to meet their expectation or not.

\subsection{Cooperative Services and Member'Satisfaction}

Multi-purpose cooperatives may be organized according to function: - 1/ production cooperatives-permits farmers to organize their farms as cooperative enterprise, 2/ supply cooperatives- purchase products and services and required inputs for agricultural production for their members, 3/ Service cooperatives- provide a wide variety of services were initially formed to serve farmers with agricultural services that are otherwise expensive for an individual to obtain. 4/ Agricultural marketing cooperatives are frequently organized according to farm commodity or groups of commodities such as sugar, grain, and poultry to produce or (usually) store and market agricultural products. Marketing cooperative structures may function as contract and price bargaining cooperatives, or may be involved in processing, assembling and packaging as well as selling member'products 
on both domestic and foreign markets. 5/ Purchasing cooperatives- buy supplies and goods and sell these at reduced price to members. This type of cooperative was first used by farmers to gain access to affordable and quality supplies such as fertilizers, feed, etc (GEAC, 2009:5) as cited by Daniel Belay (2006).

The theory of cooperative organization provides several reasons why farmers join the cooperatives. According to Schroeder (1992) as cited by Demeke (2008) cooperatives provide quality supplies and services to the farmers at the reasonable cost. By purchasing supplies as a group, the farmers offset the market power advantage of other private firms providing those supplies. The farmer can gain access to volume discounts and negotiate from a position of greater strength for better delivery terms, credit terms, and other arrangements. Increased farmers bargain power in the market places is the other advantage of the cooperative (Douglas and McConnen, 1999) as cited by Daniel Belay (April, 2006). Agricultural cooperatives contribute to the income of farmers/members by providing low cost and quality agricultural inputs and by reducing farmers' transaction costs in cooperative business participation or marketing their products (Zelalem, 2008).

\subsection{Empirical studies on Member'satisfaction}

Demeke Tilahun (2007) used financial ratio analysis and probit regression model to analyze financial performance and member satisfaction of coffee marketing cooperatives. His result showed that the cooperatives under consideration were inefficient on their business management and handling members that leads to member'dissatisfaction.

Jabessa (2010) used descriptive statistics to assess member'attitudes towards services provided by their cooperatives. His result showed that members of cooperatives under investigation were not satisfied with services delivered by the cooperative and its management.

\section{RESEARCH METHODOLOGY}

\subsection{Sampling Techniques and Sample size determination}

In the study area there are $34 \mathrm{CBEs}$ from which 5 cooperatives were selected purposively. The total number of member respondents was determined by using Kothari (2004) sampling design formula and PPS was used to select member respondents from each selected cooperatives.

Table 1: Sample units of respondents

\begin{tabular}{|l|l|r|r|r|r|}
\hline \multirow{2}{*}{ S.No } & Name of primary cooperatives & \multicolumn{3}{|c|}{ Number of Members } & \multirow{2}{*}{ Sample Proportion } \\
\cline { 3 - 5 } & & Male & Female & Total & \\
\hline 1 & Ilili Derartu & 783 & 141 & 924 & 122 \\
\hline 2 & Hunde Gudina & 259 & 41 & 300 & 39 \\
\hline 3 & Deyma damu & 449 & 14 & 463 & 61 \\
\hline 4 & Urji Ramis & 211 & 32 & 243 & 32 \\
\hline 5 & Ifa waraksa & 602 & 4 & 606 & 80 \\
\hline \multicolumn{2}{|l|}{ Total } & $\mathbf{2 3 0 4}$ & $\mathbf{2 3 2}$ & $\mathbf{2 5 3 6}$ & $\mathbf{3 3 4}$ \\
\hline
\end{tabular}

Source: Computed from Bedeno Woreda Cooperatives Promotion Bureau, 2019

$$
\boldsymbol{n}=\frac{p * q \cdot N \cdot Z^{2}}{(N-1) e^{2}+Z^{2} p * q} \quad \text { (Kothari (2004) sampling design formula) }
$$

Where:

$\mathrm{n}=$ sample size, $\mathbf{3 3 4}$

$\mathrm{N}=$ Total population 2536

$\mathrm{Z}=95 \%$ confidence interval under normal curve (1.96)

$\mathrm{e}=$ acceptable error term (0.05), and

$\mathrm{P}$ and $\mathrm{q}$ are estimates of the proportion of population to be sampled $(\mathrm{p}=0.5$ and $\mathrm{q}=0.5)$

\subsection{Types and sources of data}

The data needed was collected from both primary and secondary sources. Five years secondary data was collected from diverse sources including records of sampled CBEs and Bedeno Woreda Cooperative Promotion Office. The members of selected cooperatives were considered as key sources of primary data.

\subsection{Methods of data collection}

Semi-structured interview was employed to collect the required primary data. For the sake of triangulating the data collected from member respondents, qualitative data was collected from management committee of sampled cooperatives by conducting (FGD). Five FGDs were conducted with 20 management committee, 4 from each of cooperatives through checklist. Besides, key informant interviews (KIIs) were also employed among 4 Districts` Cooperative Promoters (DCP). 


\subsection{Method of Data Analysis}

Collected data was analyzed using descriptive analytical tools like frequency description, percentage analysis and crosstab analysis.

\section{DATA ANALYSIS AND INTERPRETATION}

\subsection{Demographic Profile of Member Respondents}

The demographic characteristics of respondents such as age, gender, educational level and family size are presented below.

For the purpose of this study, based on the illegibility of cooperative membership (above 14 year), age of respondents was categorized into three categories namely; young (14-35 year), middle (36-50 year) and old age (above 50 year). The survey result indicated that majority of the respondents $184(55 \%)$ were young followed by $132(39.7 \%)$ middle age and $18(5.3 \%)$ old age respectively. It was found that majority of the respondents 252 $(75.5 \%)$ were male, while $82(24.5 \%)$ were female indicating domination of men members which needs women encouragement.

The survey result shows that majority of the respondents $130(38.9 \%)$ were illiterate, followed by $76(22.9 \%)$ who can read and write, $110(32.8 \%)$ primary (1-8 grade) and 18(5.3\%) secondary (9-12) respectively. Education is very important for members to know their rights, responsibilities and also benefits of cooperatives.

Family size refers to the number of family of members including household leader (he/she) which is expressed by numbers. The study result reveals that majority of the respondents $141(42.1 \%)$ were with small size (1-4 members) family, followed by 119(35.7\%) medium size (5-7 members) and 74 (22.2\%) big size (above 7 members). It was found that the family size of most of member respondents was small (only up to 4 members).

\subsection{Services provided by selected CBEs in Bedeno woreda}

Services provided by CBEs include agricultural input services, consumers' goods distribution and output marketing services. Agricultural input services include fertilizers and improved seeds. As evidenced from the secondary data, all cooperatives are offering fertilizers and improved seeds. With regard to consumer's goods, CBEs in Bedano district are distributing sugar and oil. However, all CBEs are undertaking coffee marketing as output marketing.

\subsubsection{Agricultural input services}

Agricultural input services are used to increase the production and productivity of agricultural outputs. Agricultural inputs offered by CBEs are fertilizers and improved seeds (Table 2).

Table 2: supplied agricultural input services

\begin{tabular}{|r|r|r|r|r|r|}
\hline & \multicolumn{3}{|c|}{ Fertilizers } & \multicolumn{3}{c|}{ Improved Seeds } \\
\hline Year & $\begin{array}{l}\text { Quantity } \\
\text { (in quintal) }\end{array}$ & $\begin{array}{l}\text { Value/quintal } \\
\text { (in ETB) }\end{array}$ & \multicolumn{1}{l|}{ Year } & $\begin{array}{l}\text { Quantity } \\
\text { (in quintal) }\end{array}$ & $\begin{array}{l}\text { Value/quintal } \\
\text { (in ETB) }\end{array}$ \\
\hline 2011 & 1165 & 1256 & 2011 & 39 & 992 \\
\hline 2012 & 2446 & 1606 & 2012 & 45 & 1696 \\
\hline 2013 & 3075 & 1978.56 & 2013 & 49 & 1824 \\
\hline 2014 & 5171 & 2616 & 2014 & 46 & 412 \\
\hline 2015 & 5803 & 2826 & 2015 & 81 & 4128 \\
\hline
\end{tabular}

Source: Computed from Annual reports (2011-2015) of Selected CBEs

As indicated in table 2, it was found that the quantity of fertilizers and improved seeds distributed to the members and value of these inputs were increasing from year to year. The percentage increase of 2015 for distributed fertilizer is $398.11 \%$ more quintals than 2011 . This shows high supply of fertilizer above the farmers' need. For this, farmers were forced to purchase fertilizer three times a year. However, the percentage increase of 2015 for improved seeds distributed to farmers is $107.6 \%$ more quintals than 2011. Although there is high increase of improved seeds supply, if compared with fertilizer supply it is lower. The percentage increase of the price of fertilizer and improved seeds in 2015 are $125.0 \%$ and $316.12 \%$ more Birr than 2011 respectively. Although there is percentage difference between the cost of both fertilizer and improved seeds, in both case it is very high and unaffordable by farmers. This high price was a key factor for the dissatisfaction of members on the supply of fertilizer and improved seeds as witnessed by most of the respondents.

\subsubsection{Consumers' Goods}

The consumers' goods distributed by Selected CBEs in Bedeno woreda include sugar and oil. These cooperatives are distributing these goods to all members only when they receive it from the local administration (see Table 3). 
Table 3: Sugar and Oil distributed by selected CBEs

\begin{tabular}{|c|c|r|r|r|r|}
\hline \multicolumn{3}{|c|}{ Sugar } & \multicolumn{3}{c|}{ Oil } \\
\hline Year & Quantity (in quintal) & Value/quintal (in ETB) & Year & Quantity (in liter) & Value/Liter(in ETB) \\
\hline 2011 & & & 2011 & & \\
\hline 2012 & & & 2012 & & \\
\hline 2013 & 38 & 14.33 & 2013 & 6055 & 21.00 \\
\hline 2014 & 46 & 14.45 & 2014 & 9039 & 21.40 \\
\hline 2015 & 42 & 14.85 & 2015 & 7381 & 22.90 \\
\hline
\end{tabular}

Source: Computed from Annual Reports (2011-2015) of Selected CBEs

As indicated in table 3, the data for sugar and oil supply for 2011 and 2012 is not available. Because, CBEs started the supply of sugar and oil from 2013 onward. It was found that the quantity and value/price of sugar and oil is increasing from year to year. This is because of high demand but low supply of sugar and oil. The percentage increase of sugar and oil supply in 2015 was $10.52 \%$ quintals and $21.90 \%$ liters more than 2013 , respectively. In contrary to this, the result of this study shows there was a decrease of supply of both commodities from 2014 - 2015. The percentage decrease of sugar and oil in 2015 was 8.70\% quintals and $18.34 \%$ liters lower than 2014, respectively. This indicates high shortage of supply of both sugar and oil to members. This forced respondents to witness dissatisfied on the distribution of consumer's goods.

\subsubsection{Output Marketing}

It was found that the output marketing by cooperative in the study area is limited to coffee only. Table 4 below presents the volume and price of coffee procured from members.

Table 4: Yearly coffee procured by selected CBEs

\begin{tabular}{|r|r|r|}
\hline Year & Quantity (in $\mathrm{kg})$ & Price/kg (in ETB) \\
\hline 2011 & 166704.30 & 34.11 \\
\hline 2012 & 175513.93 & 39.32 \\
\hline 2013 & 295930.55 & 50.88 \\
\hline 2014 & 271989.00 & 96.86 \\
\hline 2015 & 355387.00 & 105.60 \\
\hline
\end{tabular}

Source: Computed from Annual report (2011-2015) of selected CBES

As indicated in table 4, that quantity of coffee procured are increasing from year to year. The percentage increase of coffee marketing in 2015 is $113.18 \%$ quintal more than 2011 . This indicates high coffee supply to CBEs in Bedeno woreda. However, the price offered to member's produce in 2015 shows only 2.1\% Birr more increase than 2011. This is insignificant change when compared with quantity increase. 
4.2. Members' Satisfaction Level on the Services Provided by CBEs

Table 5: Opinion of Respondents about their satisfaction level on Services Provided by CBEs

\begin{tabular}{|c|c|c|c|}
\hline Services & Response & Frequency & Percent \\
\hline Fertilizer & Satisfied & 59 & 17.6 \\
\hline & Unknown & 0 & 0.00 \\
\hline & Not satisfied & 275 & 82.4 \\
\hline & Total & 334 & 100.0 \\
\hline Improved Seeds & Satisfied & 23 & 6.9 \\
\hline & Unknown & 0 & 0.00 \\
\hline & Not satisfied & 311 & 93.1 \\
\hline & Total & 334 & 100.0 \\
\hline Sugar & Satisfied & 56 & 16.8 \\
\hline & Unknown & 0 & 0.00 \\
\hline & Not satisfied & 278 & 83.2 \\
\hline & Total & 334 & 100.0 \\
\hline Oil & Satisfied & 74 & 22.1 \\
\hline & Unknown & 0 & 0.00 \\
\hline & Not satisfied & 260 & 77.9 \\
\hline & Total & 334 & 100.0 \\
\hline Coffee Marketing & Satisfied & 41 & 12.2 \\
\hline & Unknown & 0 & 0.00 \\
\hline & Not satisfied & 293 & 87.8 \\
\hline & Total & 334 & 100.0 \\
\hline
\end{tabular}

Source: Computed from survey, 2019.

Table 5 shows that, majority of the respondents, 82.4 percent opined that they are not satisfied with the fertilizer, 93.1 percent opined that they are not satisfied on improved seeds, 83.2 percent opined that they are not satisfied on sugar, 77.9 percent opined that they are not satisfied on oil and 87.8 percent opined that they are not satisfied on coffee marketing. The reasons behind dissatisfaction of members on the services provided to them by their cooperatives are high cost of fertilizers and improved seeds and low quality of improved seeds as opined by 79.4 percent and 53.8 percent respectively. The low quality of improved seeds is related to the incompatibility of the improved seeds with the local environment. With regard to output market; that is trade of coffee, the low price of coffee is the paramount factor for the member's dissatisfaction with output market service. Despite the fact that there is coffee price increase from year to year, the price coffee growers receive for their product is low as opined by all respondents (100.0 percent). Moreover, as evidenced by all respondents the distribution of services was not based on the needs of members. Rather, it is decided by agricultural and rural development office in collaboration with trade and industry office.

The result out of FGDs also revealed that the distribution of services was not based on the needs of members. The kind, quantity and quality of service are decided by the government officials in local administration. The role of cooperative is limited only to distribution of services at determined price. The result also revealed that distributed seeds sometimes face compatibility problem with local farm climate.

\subsubsection{Overall Satisfaction Level of Respondents on Services provided by CBEs}

Table 6 below presents the overall satisfaction of members on total services provided by selected CBEs.

Table 6: Opinion of respondents on overall satisfaction on services

\begin{tabular}{|l|r|r|}
\hline Satisfaction Response & Frequency & \multicolumn{2}{|c|}{ Percent } \\
\hline Satisfied & 140 & 42.0 \\
\hline Unknown & 0 & 0.00 \\
\hline Not satisfied & 194 & 58.0 \\
\hline Total & 334 & 100.0 \\
\hline
\end{tabular}

Source: Computed from survey, 2019

Table 6, shows that majority of the respondents, 194(58\%) opined that they are not satisfied on the overall services of their cooperatives followed by $140(42 \%)$ who agreed they are satisfied on the overall services provided by CBEs. This result shows that majority of the respondents are not satisfied. It is evident from previous analysis that the cost of service is high, quality is low, the supplied quantity is below the demand of members, and also not delivered on time. All these factors led respondents to rate their overall opinion on services provided by selected CBEs as not satisfied. 


\subsection{Results of Crosstab Analysis}

Crosstab analysis was undertaken to check whether member'satisfaction on service provided by CBEs is dependent on the demographic characteristics of members (age, gender, educational level and family size).

Age, Gender, Educational level and Family Size of Respondents Vs Satisfaction on Agricultural Input Supply

The result of crosstab analysis shows that from the total respondents opined that they are satisfied on the supplied agricultural inputs, 62.1 percent was young. The result also indicated that from the total respondents opined as not satisfied, 53.3 percent was young (See Table 7). This shows that the highest percentage of both satisfied and not satisfied is young members. It was further found out that, members' satisfaction on the supplied agricultural inputs decrease as age of the members increase from young to old. So, member's satisfaction on agricultural inputs is highly dependent on age of member users.

The result of crosstab analysis shows that majority of member respondents opined that they are not satisfied on agricultural input services provided by CBEs, 77.7 percent was male. Further, it was found that from the total respondents opined that they are satisfied on the supplied agricultural inputs, 67.0 percent was male. Thus, member's satisfaction on agricultural input is highly dependent on the gender of respondents.

Table 7: age, gender, educational level and family size Vs satisfaction with input services

\begin{tabular}{|c|c|c|c|}
\hline \multirow{2}{*}{$\begin{array}{ll}\text { Category } & \text { Response } \\
\end{array}$} & \multicolumn{2}{|c|}{ Satisfaction response } & \multirow[t]{2}{*}{ Total } \\
\hline & Satisfied & Not satisfied & \\
\hline \multicolumn{4}{|l|}{ Age } \\
\hline Young (14-35) & $\begin{array}{r}41 \\
(62.1) \\
\end{array}$ & $\begin{array}{r}143 \\
(53.3) \\
\end{array}$ & $\begin{array}{r}184 \\
(55.0) \\
\end{array}$ \\
\hline Middle (36-50) & $\begin{array}{r}25 \\
(37.9)\end{array}$ & $\begin{array}{r}107 \\
(40.0)\end{array}$ & $\begin{array}{r}132 \\
(40.0)\end{array}$ \\
\hline Old $(>50)$ & 0 & $\begin{array}{r}18 \\
(6.7) \\
\end{array}$ & $\begin{array}{r}18 \\
(5.0) \\
\end{array}$ \\
\hline Total & $\begin{array}{r}66 \\
(100.0) \\
\end{array}$ & $\begin{array}{r}268 \\
(100.0) \\
\end{array}$ & $\begin{array}{r}334 \\
(100.0) \\
\end{array}$ \\
\hline \multicolumn{4}{|l|}{ Gender } \\
\hline Male & $\begin{array}{c}56 \\
(67.0) \\
\end{array}$ & $\begin{array}{r}194 \\
(77.7) \\
\end{array}$ & $\begin{array}{r}252 \\
(75.5) \\
\end{array}$ \\
\hline Female & $\begin{array}{r}28 \\
(33.0) \\
\end{array}$ & $\begin{array}{r}56 \\
(22.3) \\
\end{array}$ & $\begin{array}{r}82 \\
(24.5) \\
\end{array}$ \\
\hline Total & $\begin{array}{r}84 \\
(100.0) \\
\end{array}$ & $\begin{array}{r}250 \\
(100.0) \\
\end{array}$ & $\begin{array}{r}334 \\
(100.0) \\
\end{array}$ \\
\hline \multicolumn{4}{|l|}{ Educational level } \\
\hline Illiterate & $\begin{array}{r}30 \\
(42.2)\end{array}$ & $\begin{array}{r}100 \\
(38.0)\end{array}$ & $\begin{array}{r}130 \\
(39.0)\end{array}$ \\
\hline Read And Write & $\begin{array}{r}20 \\
(28.2) \\
\end{array}$ & $\begin{array}{r}56 \\
(21.3) \\
\end{array}$ & $\begin{array}{r}76 \\
(23.0) \\
\end{array}$ \\
\hline Primary (1-8) & $\begin{array}{r}18 \\
(25.4)\end{array}$ & $\begin{array}{r}92 \\
(35.0)\end{array}$ & $\begin{array}{r}110 \\
(33.0)\end{array}$ \\
\hline Secondary (9-12) & $\begin{array}{r}3 \\
(4.2) \\
\end{array}$ & $\begin{array}{r}15 \\
(5.7) \\
\end{array}$ & $\begin{array}{r}18 \\
(5.0) \\
\end{array}$ \\
\hline Total & $\begin{array}{r}71 \\
(100.0) \\
\end{array}$ & $\begin{array}{r}263 \\
(100.0) \\
\end{array}$ & $\begin{array}{r}334 \\
(100.0) \\
\end{array}$ \\
\hline \multicolumn{4}{|l|}{ Family Size } \\
\hline Small(1-4) & $\begin{array}{r}48 \\
(38.4) \\
\end{array}$ & $\begin{array}{r}93 \\
(44.4) \\
\end{array}$ & $\begin{array}{r}141 \\
(35.7) \\
\end{array}$ \\
\hline $\operatorname{Medium}(5-8)$ & $\begin{array}{r}38 \\
(30.4)\end{array}$ & $\begin{array}{r}81 \\
(38.7)\end{array}$ & $\begin{array}{r}119 \\
(42.1)\end{array}$ \\
\hline Big(Above 8) & $\begin{array}{r}39 \\
(31.2) \\
\end{array}$ & $\begin{array}{r}35 \\
(16.9) \\
\end{array}$ & $\begin{array}{r}74 \\
(22.2) \\
\end{array}$ \\
\hline Total & $\begin{array}{r}125 \\
(100.0) \\
\end{array}$ & $\begin{array}{r}209 \\
(100.0) \\
\end{array}$ & $\begin{array}{r}334 \\
(100.0) \\
\end{array}$ \\
\hline
\end{tabular}

Source: Computed from survey, 2019.

Figures in brackets are percentage to column total

Moreover, the survey result shows that from the total respondents opined that they are satisfied on the supplied input services, 42.2 percent was illiterate. The result also revealed that from the total respondents 
opined that they are not satisfied on agricultural input services, 38.0 percent was also illiterate. Thus, it can be generalized that member's satisfaction on agricultural input services is highly dependent on the level of education of members.

The result also indicated that, among all respondents witnessed they are not satisfied on the supplied agricultural inputs, 44.4 percent was with small family size. From the total respondents opined that they are satisfied on the supplied input services, 38.4 percent was again with small family size (see Table 7). It was further found that the percentage of satisfied and not satisfied on agricultural input services decrease as family size increase from small to big size. So, it can be generalized that member's satisfaction on agricultural input provided by CBEs is highly dependent on family size of members.

\section{Age, Gender, Educational level and Family Size Vs Satisfaction on Consumers` Goods supplied}

The result of crosstab analysis shows that from the total respondents opined that they are satisfied on consumers' goods distributed to them, 60.9 percent was young and from the total respondents opined that they are not satisfied on the supplied goods 53.7 percent was young. Furthermore, it was found that the satisfaction decrease as age increase from young to old (see Table 8). It is evident from previous analysis that majority of members of CBEs were young. So, we can deduce that member's satisfaction on the supplied consumer's goods like sugar and oil is highly dependent on the age of members.

Table 8 age, gender, education level and family size Vs satisfaction on the consumers' goods

\begin{tabular}{|c|c|c|c|}
\hline \multirow{2}{*}{$\begin{array}{ll}\text { Category } & \text { Response } \\
\end{array}$} & \multicolumn{2}{|c|}{ Satisfaction response } & \multirow[t]{2}{*}{ Total } \\
\hline & Satisfied & Not satisfied & \\
\hline \multicolumn{4}{|l|}{ Age } \\
\hline Young(14-35) & $\begin{array}{r}39 \\
(60.9)\end{array}$ & $\begin{array}{r}145 \\
(53.7)\end{array}$ & $\begin{array}{r}184 \\
(55.0)\end{array}$ \\
\hline Middle(36-50) & $\begin{array}{r}22 \\
(34.0)\end{array}$ & $\begin{array}{r}110 \\
(40.7)\end{array}$ & $\begin{array}{r}132 \\
(39.7)\end{array}$ \\
\hline Old $(>50)$ & $\begin{array}{r}3 \\
(5.0)\end{array}$ & $\begin{array}{r}15 \\
(5.6)\end{array}$ & $\begin{array}{r}18 \\
(5.3)\end{array}$ \\
\hline Total & $\begin{array}{r}64 \\
(100.0)\end{array}$ & $\begin{array}{r}270 \\
(100.0)\end{array}$ & $\begin{array}{r}334 \\
(100.0)\end{array}$ \\
\hline \multicolumn{4}{|l|}{ Gender } \\
\hline Male & $\begin{array}{r}38 \\
(59.4)\end{array}$ & $\begin{array}{r}214 \\
(79.3)\end{array}$ & $\begin{array}{r}252 \\
(75.5) \\
\end{array}$ \\
\hline Female & $\begin{array}{r}26 \\
(40.6)\end{array}$ & $\begin{array}{r}56 \\
(20.7)\end{array}$ & $\begin{array}{r}82 \\
(24.5)\end{array}$ \\
\hline Total & $\begin{array}{r}64 \\
(100.0) \\
\end{array}$ & $\begin{array}{r}270 \\
(100.0) \\
\end{array}$ & $\begin{array}{r}334 \\
(100.0) \\
\end{array}$ \\
\hline \multicolumn{4}{|l|}{ Educational level } \\
\hline Illiterate & $\begin{array}{r}29 \\
(45.0) \\
\end{array}$ & $\begin{array}{r}101 \\
(37.4) \\
\end{array}$ & $\begin{array}{r}130 \\
(38.9) \\
\end{array}$ \\
\hline Read And Write & $\begin{array}{r}7 \\
(11.0)\end{array}$ & $\begin{array}{r}69 \\
(25.5) \\
\end{array}$ & $\begin{array}{r}76 \\
(22.8)\end{array}$ \\
\hline Primary(1-6) & $\begin{array}{r}28 \\
(44.0)\end{array}$ & $\begin{array}{r}82 \\
(30.4)\end{array}$ & $\begin{array}{r}110 \\
(32.9)\end{array}$ \\
\hline Secondary(7-12) & $\begin{array}{r}0 \\
(.0)\end{array}$ & $\begin{array}{r}18 \\
(6.7)\end{array}$ & $\begin{array}{r}18 \\
(5.4)\end{array}$ \\
\hline Total & $\begin{array}{r}64 \\
(100.0)\end{array}$ & $\begin{array}{r}270 \\
(100.0) \\
\end{array}$ & $\begin{array}{r}334 \\
(100.0)\end{array}$ \\
\hline \multicolumn{4}{|l|}{ Family Size } \\
\hline Small(1-4) & $\begin{array}{r}21 \\
(32.8)\end{array}$ & $\begin{array}{r}120 \\
(44.4)\end{array}$ & $\begin{array}{r}141 \\
(35.7) \\
\end{array}$ \\
\hline Medium(5-8) & $\begin{array}{r}22 \\
(34.4) \\
\end{array}$ & $\begin{array}{r}97 \\
(36.0) \\
\end{array}$ & $\begin{array}{r}119 \\
(42.1) \\
\end{array}$ \\
\hline Big (Above 8) & $\begin{array}{r}21 \\
(32.8 .0) \\
\end{array}$ & $\begin{array}{r}53 \\
(19.6) \\
\end{array}$ & $\begin{array}{r}74 \\
(22.2) \\
\end{array}$ \\
\hline Total & $\begin{array}{r}64 \\
(100.0)\end{array}$ & $\begin{array}{r}270 \\
(100.0)\end{array}$ & $\begin{array}{r}334 \\
(100.0)\end{array}$ \\
\hline
\end{tabular}

\footnotetext{
Source: Computed from survey, 2019.
}

Figures in brackets are percentages to column total

Table 8 revealed that among respondents opined that they are satisfied on supplied goods, 59.4 percent were 
male. The result also shows that from total respondents opined that they are not satisfied on the supplied goods 79.3 percent were male. So, member's satisfaction on the supplied consumer's goods is highly dependent on gender.

The result of crosstab analysis revealed that from the total respondents opined that they are satisfied on the supplied consumers ' goods, 45.0 and 44.0 percent were illiterate and those who attended primary school. Table 8 also shows that from the total respondents opined that they are not satisfied on the supplied consumers' goods, 37.4 percent were illiterate. It is evident from previous analysis that majority of members of CBE were illiterate and those attained primary school. So, satisfaction is highly dependent on the level of education of members. Moreover the result of crosstab analysis shows that from the total respondents opined that they are satisfied on the supplied consumers' goods, 34.8 percent were with medium family size whereas 44.4 percent of respondents not satisfied on the supplied service were with small family size.

\section{Age, Gender, Educational level and Family Size Vs Satisfaction on output marketing}

The result of crosstab analysis shows that from total respondents opined that they are satisfied on output marketing services, 62.5 percent were young members and among total respondents opined that they are not satisfied on output marketing services 51.3 percent were also young members (Table 9). Moreover, it was found that the percentage of both satisfied and not satisfied on output marketing services provided by CBEs decreases as the age of respondents increase from young to old. It is also evident from previous analysis that majority of members of CBEs were young aged. So, member's satisfaction on output marketing is highly dependent on the age of members.

The survey result also indicates that from the total respondents opined that they are satisfied on output marketing services provided by CBEs, 93.1 percent were male and 59.4 percent of respondents not satisfied on output marketing services were also male. It is evident from previous analysis that majority of members of CBE were male. So, member's satisfaction on output marketing is highly dependent on the gender of members.

Table 9: age, gender, education level and family size Vs Satisfaction on output marketing

\begin{tabular}{|c|c|c|c|}
\hline \multirow{2}{*}{ Category $\quad$ Responses } & \multicolumn{2}{|c|}{ Satisfaction response } & \multirow[t]{2}{*}{ Total } \\
\hline & Satisfied & Not Satisfied & \\
\hline \multicolumn{4}{|l|}{ Age } \\
\hline Young(14-35) & $\begin{array}{r}70 \\
(62.5)\end{array}$ & $\begin{array}{r}114 \\
(51.3)\end{array}$ & $\begin{array}{r}184 \\
(55.1)\end{array}$ \\
\hline Middle(36-50) & $\begin{array}{r}35 \\
(31.2)\end{array}$ & $\begin{array}{r}97 \\
(43.7)\end{array}$ & $\begin{array}{r}132 \\
(39.5)\end{array}$ \\
\hline Old $(>50)$ & $\begin{array}{r}7 \\
(6.3)\end{array}$ & $\begin{array}{r}11 \\
(5.0)\end{array}$ & $\begin{array}{r}18 \\
(5.4)\end{array}$ \\
\hline Total & $\begin{array}{r}112 \\
(100.0)\end{array}$ & $\begin{array}{r}222 \\
(100.0)\end{array}$ & $\begin{array}{r}334 \\
(100.0)\end{array}$ \\
\hline \multicolumn{4}{|l|}{ Gender } \\
\hline Male & $\begin{array}{r}148 \\
(93.1)\end{array}$ & $\begin{array}{r}104 \\
(59.4)\end{array}$ & $\begin{array}{r}252 \\
(75.4) \\
\end{array}$ \\
\hline Female & $\begin{array}{r}11 \\
(6.9) \\
\end{array}$ & $\begin{array}{r}71 \\
(40.6) \\
\end{array}$ & $\begin{array}{r}82 \\
(24.6) \\
\end{array}$ \\
\hline Total & $\begin{array}{r}159 \\
(100.0) \\
\end{array}$ & $\begin{array}{r}175 \\
(100.0) \\
\end{array}$ & $\begin{array}{r}334 \\
(100.0) \\
\end{array}$ \\
\hline \multicolumn{4}{|l|}{ Educational level } \\
\hline Illiterate & $\begin{array}{r}39 \\
(50.0)\end{array}$ & $\begin{array}{r}91 \\
(35.5)\end{array}$ & $\begin{array}{r}130 \\
(38.9) \\
\end{array}$ \\
\hline Read And Write & $\begin{array}{r}21 \\
(27.0)\end{array}$ & $\begin{array}{r}55 \\
(21.5)\end{array}$ & $\begin{array}{r}76 \\
(22.8)\end{array}$ \\
\hline Primary(1-6) & $\begin{array}{r}16 \\
(20.5)\end{array}$ & $\begin{array}{r}84 \\
(32.8)\end{array}$ & $\begin{array}{r}100 \\
(29.9)\end{array}$ \\
\hline Secondary $(7-12)$ & $\begin{array}{r}2 \\
(2.5)\end{array}$ & $\begin{array}{r}26 \\
(10.2)\end{array}$ & $\begin{array}{r}28 \\
(8.4)\end{array}$ \\
\hline Total & $\begin{array}{r}78 \\
(100.0) \\
\end{array}$ & $\begin{array}{r}256 \\
(100.0) \\
\end{array}$ & $\begin{array}{r}334 \\
(100.0) \\
\end{array}$ \\
\hline \multicolumn{4}{|l|}{ Family size } \\
\hline Small(1-4) & $\begin{array}{r}24 \\
(58.5) \\
\end{array}$ & $\begin{array}{r}117 \\
(40.0) \\
\end{array}$ & $\begin{array}{r}141 \\
(35.7) \\
\end{array}$ \\
\hline Medium(5-7) & $\begin{array}{r}12 \\
(29.3) \\
\end{array}$ & $\begin{array}{r}107 \\
(36.5) \\
\end{array}$ & $\begin{array}{r}119 \\
(42.1) \\
\end{array}$ \\
\hline
\end{tabular}




\begin{tabular}{|l|r|r|r|}
\hline \multirow{2}{*}{ Category } & \multicolumn{2}{|c|}{ Sesponses } & \multicolumn{2}{|c|}{ Totasfaction response } \\
\cline { 2 - 3 } & \multicolumn{1}{|c|}{ Satisfied } & Not Satisfied & \\
\hline Big(Above 7) & 5 & 69 & 74 \\
& $(12.2)$ & $(23.5)$ & $(22.2)$ \\
\hline Total & 41 & 293 & 334 \\
& $(100.0)$ & $(100.0)$ & $(100.0)$ \\
\hline
\end{tabular}

Source: Computed from survey, 2019.

Figures in brackets are percentages to column total

Table 9 shows that 50.0 percent of respondents satisfied on output marketing services provided by CBEs were illiterate and 35.5 percent of respondents not satisfied on output marketing services provided by CBEs were also illiterate. The result also shows that the highest percentage of both respondents satisfied and not satisfied on output marketing services were illiterate. This indicates that member's satisfaction is highly dependent on the member's education level.

With regard to family size of members, the crosstab analysis shows that from the total respondents satisfied on output marketing services, 58.5 percent were with small family size and 40.0 percent of respondents not satisfied on output marketing services were also with small family size (See Table 9). So, it is advisable to conclude that member's satisfaction on output marketing is highly dependent on the family size of members.

\subsection{Results of FGDs and KIIs}

From the analysis of FGD and KII, the same result was obtained. It is presented as follow;

- Cooperatives were not offering all services required by members.

- The cost of agricultural input is high.

- There were problem of improved seeds in terms of climate compatibility.

- Cost of service was not decided by cooperatives.

- Quality of improved seeds was low.

- Improved seeds, sugar and oil was not available by the required amount and at right time since government officials give priority to private traders.

\section{CONCLUSION AND RECOMMENDATIONS}

\subsection{Conclusion}

The service offered by selected CBEs includes supply of agricultural inputs, distribution of consumers' goods and output marketing services. Agricultural input services offered by CBEs are fertilizer and improved seeds. Fertilizer was supplied above the demand of farmers and it is distributed three times per year. But improved seed is not available by the required amount and not delivered on time. The quality of improved seeds is low and sometimes not compatible with the local farm climate. The cost of both fertilizer and improved seeds is high. Consumers` goods distributed by CBEs include sugar and oil. The cost of sugar and oil is high. Consumers' goods distribution (sugar and oil) is not available by the required amount and not delivered on time. The survey result indicated that members are not satisfied with the services offered of by their cooperatives.

The result of crosstab analysis shows that, member'satisfaction on service provided by CBEs is dependent on the demographic characteristics of members like age, gender, educational level and family size as witnessed by most young, male members with small family size. To conclude, it is found that majority of the members are not satisfied on service provided by their cooperatives.

\subsection{Recommendations}

Based on the findings of the study, the following points are recommended to increase member'satisfaction on the services provided by CBEs.

- In addition to currently available services such as fertilizer, improved seeds, sugar, oil and coffee marketing service, CBEs in Bedeno district should offer other additional services like credit service, biochemical agricultural inputs, market information, storage service, transportation and other services required by members.

- The services should be provided on time and should be customer/member/user oriented. Cooperatives operating in the area, especially selected cooperatives should offer quality services at affordable price to members. There supplied services should be fair in terms of the quantity and quality. Cooperatives should provide high price for member'output (coffee) by searching new market like foreign market. Other farmer's products especially cash crops like sesame, kat (jima), etc should be the target of CBEs. To do these CBEs should prepare well their grounds.

At the outset since members are the primary stakeholders of cooperatives, their needs and requirements must be fulfilled, and they are to be satisfied in all aspects. 


\section{REFERENCES}

Agbo, Festus Ugwuoke \& Onah, Ogochukwu. G, (2003), Economic Analysis Of Farmers Access To The Services Of Farmers Multipurpose Cooperative Societies (FMCS) In Enugu North Agricultural Zone Of Enugu State, Nigeria, Department of Agricultural Economics, University of Nigeria, Nsukka, Nigeria, International Journal of Agricultural Science and Research (IJASR) Vol. 3 Issue 2

Anderson, C.J. and Vincze, J.W., (2000). Strategic Marketing Management. Houghton Mifflin Company.New York.

Aref, F. (2011) Rural Cooperatives for Poverty Alleviation in Iran. Life Science Journal 8

Bhuyan S and Olson F (1998). Potential role of non-agricultural cooperatives in rural development: a report on focus group studies conducted in rural North Dakota. Agricultural Economics Report No. 383. North Dakota State University, USA.

Burt, L., (1997) Organizing and Operating Agricultural Cooperatives. Oregon State University. U.S.A.

Chukwu S.K., (1990), Economies of the Cooperative Busines Enterprise, Marbg, Germany

Daniel Belay, (2006). Performance of Agricultural cooperatives and Determinants of Member'Decision to Use As a Marketing Agent in Ada liben (Unpublished) M. sc. Thesis, Haramaya University, Ethiopia

Demeke Tilahun(2008), Preformance of Coffee Marketing Cooperatives and Member'Satisfaction in Dale District SNNP, M.Sc. Thesis, Haramaya University, Ethiopia

Department for International Development (DFID) (2010). Working with Cooperatives for Poverty Reduction. http://www.co-op.ac.uk/wp-content/uploads/2010/08/Cooperatives-Briefing-pdf.

ICA (2005). International Cooperative Alliance http://www.ica.coop/ (accessed 18/04/2018).

Krishnaswami O.R. and Kulandaiswamy V, (2000). Cooperation: Concept and theory. Arudra Academy, India. Kothari (2004). Research Methodology, Methods and Techniques, New Age International Limited Publishers. NCBA (National Cooperative Business Association) (2007).http://www.ncba.org/ (accessed on 15/03/2019).

Zelalem Ejigu (2008). The economic impact of agricultural cooperatives on small holder farmers-the case of Toke Kutaye woreda, Oromia region, Ambo University, Ethiopia. 